\title{
Phytophagous and Predacious Mites of Economic Importance on Date Palms in Dakahleya and New Valley Governorates Ola M. Roshdy ${ }^{1}$; A. S. Ameen ${ }^{2}$; Mona M. Ghallab ${ }^{3}$ and A. M. Hussein ${ }^{3}$ \\ ${ }^{1}$ Plant Protection Research Institute (Manssoura), ARG \\ ${ }^{2}$ Plant Protection Research Institute (New Valley), ARG \\ ${ }^{3}$ Plant Protection Research Institute, ARG, Dokki, Giza
}

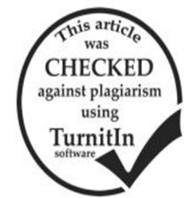

\section{ABSTRACT}

Phytophagous mites and their natural enemies associated with the date palm trees, Phoenix dactylifera L. in two environmental localities (Gamassa village, Dakahleya Governorate and El-Kharga village, New Valley Governorate) were studied from April 2016 to March 2017. Correlation between population density of studied mites and weather factors (minimum and maximum temperature) at both Governorates over the year was reported. The survey revealed the presence of 13 species of 11 genera belonging to nine families in Gamassa village, while mites of El-Kharga village were two mite species belonging to two families and three species of predators of low populations.

Keywords: Colopalpus eriophyoides, date palm trees, phytophagous mites, Phyllotetranychus aegypticus, predaceous mites, Tenuipalpidae, Tetranychidae.

\section{INTRODUCTION}

The date palm trees, Phoenix dactylifera L. are distributed all over Egypt, widely cultivated in arid region of the Middle East and North Africa. Arab countries however contain $78.3 \%$ of the total world date palm trees, which demonstrated $75 \%$ of the production (El-Sebay and Abbas 2008). Survey of mites associated with palm trees was studied by many authors; El-Sanady and Mohamed (2013), Radwan and Attia (2013) and Mesbah (2014).

Tetranychidae and Tenuipalpidae are families of the subclass Acari, which form an important part of the class Arachnida, which contain most of the known mite species of worldwide distribution that have an economic importance as plant pests; therefore, these mites cause serious damage to agricultural crops, and ornamental plants. (Jeppson et al., 1975). Their feeding results in the removal of chlorophyll and causes a silvery appearance to the plant tissue due to total light reflection in the air penetrated epidermal cells (Kloft and Kunkel, 1969). This appearance turns later to be rusty, heavy infestations result in a blotching, stippling or bronzing of the leaves, sometimes accompanied by leaf fall and fruit may be scarred. These mites are considered to be among the most important pests of agricultural crops worldwide.

Using natural enemies as a biological control is an alternative and effective strategy to manage different pests in agricultural systems. Most of the well-known and most efficient predators against phytophagous mite pests in the field belong to family Phytoseiidae. In addition, families Stigmaeidae, Cheyletidae, Cunaxidae, Bdellidae and Eupallopsellidae contain predaceous species that can play an important role on the complex of phytophagous mites, eggs and immature stages of small insects (Zaher 1986).

This work aimed to mention the appearance of the phytophagous mites of economic importance on the date palm trees with their occurrence, and their associated predatory mites in Dakahleya and New Valley Governorates.

\section{MATERIALS AND METHODS}

Two field experiments were conducted in two different environmental localities, "El-Kharga", new valley Governorate, Southern of Egypt and "Gamassa", Dakahleya Governorate, North of Egypt in order to survey the different phytophagous mites infesting date palms, $P$. dactylifera and their associated natural enemies. Minimum and maximum temperatures were obtained from the Meteorological Station of Central Laboratory for Agricultural Climate (CLAC), Agriculture Research Center, during the period of study.

\section{Counting of the phytophagous mites}

An old orchard of more than 100 palm date trees, "semi dry" variety (common name: Saeidy) located in ElKharga, and another orchard in Gamassa (50 palm date trees) were chosen to survey the phytophagous mites on palms. The two orchards received all normal agriculture practices where the date palm trees were sprayed with sulfur in June against insects and spider mite pests.

In El-Kharga village, three palms were selected representing the entire orchard; monthly samples of 30 fronds were randomly picked from three age stages of palm fronds (old, moderate and new age) and continued for a year (2016-2017). Each age stage of 10 fronds was individually placed into paper bags and transferred to the laboratory. In Gamassa village, 20 fronds from four palm trees were randomly picked up and continued for the same period. Numbers of adults, nymphs and larvae attacked the leaf surfaces and their associated natural enemies were recorded by the aid of the Stereo-binocular microscope. Mites were isolated by using a fine camel hairbrush and mounted in Hoyer's medium (Perring et al., 1996) on glass microscopic slides for identification. The specimens were examined using a light microscope. Sampling continued monthly for one year. The identification of mites based on keys given by Krantz and walter (2009), Zaher (1986) and AI-Gboory (1987).

Data Analysis

Analysis of variance was conducted by one-way ANOVA to determine the significance among means of the frond age stages by using the portable statistical analysis SAS 9.3.1. Whereas the means were compared through LSD tests at 0.05 level (Wilkinson and Leland, 1999).

The simple Correlation coefficient was also calculated by using Pearson Simple Correlation Coefficient Calculator $(*)$

\section{RESULTS AND DISCUSSION}

Population abundance of mites infesting palms in Gamassa village

Obtained results of mites collected from date palms in Gamassa indicated the occurrence of four species of 
phytophagous mites, five species of predaceous mites and four saprophagous mites, which belong to three orders, nine families and eleven genera as shown in (Table 1 and Fig. 1).

\section{A- Phytophagous mites}

These mites represented $32.37 \%$ of the total collected mites (504.35 individuals) in the study, comprise four genera belonging to two families as follow:

\section{1- Family Tetranychidae Donnadieu}

Two genera were recorded from this family on date palm trees representing together $60.4 \%$ of the total collected phytophagous mites (163.25 individuals)

The dust mite, Oligonychus afrasiaticus Mc Gregor

This pest collected from date fruits and the upper surface of fronds, the abundance of this pest fluctuated in spring and autumn months with high population, while the highest peak was observed in June, which averaged 11.55

Table 1.Population of the different mite species associated with date palm trees in Gamassa village

\begin{tabular}{|c|c|c|c|c|c|c|c|c|c|c|c|c|c|c|}
\hline Mites & Mar- & Apr- & May & Jun- & Jul- & Aug- & Sep- & Oct- & Nov- & Dec- & Jan- & Feb- & Total & Percentage \\
\hline \multirow{2}{*}{\multicolumn{14}{|c|}{ Phytophagous mites }} & \multirow{8}{*}{$32.37 \%$} \\
\hline & & & & & & & & & & & & & & \\
\hline $\begin{array}{l}\text { Oligonychus } \\
\text { afrasiaticus }\end{array}$ & 6.9 & 9.85 & 8.1 & 11.55 & 0 & 0 & 8 & 11.05 & 2.85 & 0 & 0 & 0 & 58.3 & \\
\hline $\begin{array}{l}\text { Eutetranychus } \\
\text { orientalis }\end{array}$ & 6.25 & 5.1 & 5.3 & 6.45 & 0.9 & 0 & 6.1 & 9.1 & 1.25 & 0 & 0 & 0 & 40.45 & \\
\hline \multicolumn{14}{|l|}{ Tenuipalpidae } & \\
\hline Raoiella indica & 2.1 & 3 & 3.65 & 1.8 & 0 & 0 & 3.2 & 1.55 & 0 & 0 & 0 & 0 & 15.3 & \\
\hline $\begin{array}{l}\text { Brevipalpus } \\
\text { obovatus }\end{array}$ & 8.05 & 8.3 & 4.1 & 3.8 & 1.8 & 0 & 6.55 & 8.7 & 7.9 & 0 & 0 & 0 & 49.2 & \\
\hline Total & 23.3 & 26.25 & 21.15 & 23.6 & 2.7 & 0 & 23.85 & 30.4 & 12 & 0 & 0 & 0 & 163.25 & \\
\hline
\end{tabular}

Phytoseiidae

\begin{tabular}{|c|c|c|c|c|c|c|c|c|c|c|c|c|c|c|}
\hline Amblyseius hutu & 8.9 & 7.7 & 5.35 & 4.1 & 0 & 3.05 & 8 & 11.05 & 10.4 & 0 & 0 & 0 & 58.55 & \multirow{5}{*}{$34.67 \%$} \\
\hline Amblyseius swirskii & 4.85 & 6.05 & 2.9 & 0.7 & 0 & 0 & 9.25 & 9.25 & 7 & 0 & 0 & 0 & 40 & \\
\hline $\begin{array}{l}\text { Stigmaeidae } \\
\text { Agistemus exsertus }\end{array}$ & 5.95 & 4 & 2.9 & 4.85 & 0 & 0 & 3.2 & 9.25 & 2.45 & 0 & 0 & 0 & 32.6 & \\
\hline $\begin{array}{l}\text { Cheyletidae } \\
\text { Cheletogenes } \\
\text { ornatus }\end{array}$ & 0 & 2.1 & 0 & 0 & 0 & 0 & 3.2 & 1.3 & 3.65 & 0 & 0 & 0 & 10.25 & \\
\hline $\begin{array}{l}\text { Eupalopsellidae } \\
\text { Saniosulus nudus } \\
\text { Total }\end{array}$ & $\frac{5.95}{25.65}$ & $\frac{4.8}{24.65}$ & $\begin{array}{c}2.9 \\
14.05\end{array}$ & $\begin{array}{c}1.2 \\
10.85\end{array}$ & $\begin{array}{l}0 \\
0\end{array}$ & $\frac{0}{3.05}$ & $\begin{array}{l}9.25 \\
32.9\end{array}$ & $\begin{array}{c}7.1 \\
37.95\end{array}$ & $\frac{2.25}{25.75}$ & $\begin{array}{l}0 \\
0\end{array}$ & $\begin{array}{l}0 \\
0\end{array}$ & $\begin{array}{l}0 \\
0\end{array}$ & $\begin{array}{c}33.45 \\
174.85\end{array}$ & \\
\hline Tarsonemidae & \multicolumn{13}{|c|}{ Miscellaneous mites } & \multirow{8}{*}{$32.96 \%$} \\
\hline Tarsonemus stiffer & 8.05 & 7.7 & 5.35 & 9.15 & 0 & 0 & 7.9 & 11.5 & 5.85 & 0 & 0 & 0 & 55.5 & \\
\hline $\begin{array}{l}\text { Tarsonemus } \\
\text { gladifer }\end{array}$ & 8.9 & 12.65 & 6.75 & 4.95 & 0 & 0 & 10.75 & 11.95 & 2.6 & 0 & 0 & 0 & 58.55 & \\
\hline $\begin{array}{l}\text { Tydeidae } \\
\text { Tydeus californicus }\end{array}$ & 5.05 & 3.7 & 4.9 & 2.15 & 0 & 0 & 4.8 & 6.45 & 3.2 & 0 & 0 & 0 & 30.25 & \\
\hline $\begin{array}{l}\text { Acaridae } \\
\text { Tyrophagus } \\
\text { putrescentae }\end{array}$ & 1.6 & 7.4 & 3.8 & 0 & 0 & 0 & 3.1 & 5.3 & 0.75 & 0 & 0 & 0 & 21.95 & \\
\hline Total & 23.6 & 31.45 & 20.8 & 16.25 & 0 & 0 & 26.55 & 35.2 & 12.4 & 0 & 0 & 0 & 166.25 & \\
\hline Mini Temp. & 15 & 19 & 23 & 24 & 24 & 26 & 24 & 22 & 15 & 10 & 11 & 10 & & \\
\hline Max.Temp. & 26 & 33 & 37 & 32 & 33 & 37 & 38 & 27 & 25 & 16 & 15 & 15 & & \\
\hline
\end{tabular}

Mean numbers of mites on date palm trees/ fonds in Gamassa village

The citrus brown mite, Eutetranychus orientalis Klein

The total abundance of this pest throughout the study was 40.45 individuals / frond with two annual peaks, in June and October of means 6.45, 9.1 individuals, respectively, at temperature ranged between $24-32^{\circ} \mathrm{C}$ and $22-27^{\circ} \mathrm{C}$ in the two previous months, respectively (Table 1).

It was observed that $E$. orientalis was active on palm trees during moderate temperature between $22-32^{\circ} \mathrm{C}$, individuals when temperature ranged between $24-32^{\circ} \mathrm{C}$. The total abundance of this pest throughout the study was 58.3 individuals / frond representing $35.8 \%$ of the collected phytophagous mites (Table 1). Low temperature during December to February reduced the population.

O. afrasiaticus was collected also from date fruits in April and May, where its abundance on dates exceeded their occurrence on fronds (12 individuals in April), producing scar tissues on date skin, causing it to harden crack and shrivel with subsequent reduction in fruit grade marketing.

This result coincides with Negm et al., (2007) who reported that $O$. afrasiaticus infests leaves and feeds on date palm on both sides, mainly along the midrib and at high infestation levels. 


\section{2- Family Tenuipalpidae Berlese}

The red palm mite, Raoiella indica Hirst

The population abundance of these tenuipalpid mites appeared in low numbers in spring and autumn months, the highest peak was recorded in May (3.65 individuals) when the temperature ranged between 23 $37^{\circ} \mathrm{C}$, but disappeared in winter months. This result corresponds to that of Mesbah (2014) who proved the abundant of this pest in spring months.

Rodrigues et al. (2007) recorded this mite feeding close to the leaf midrib in the two sides of the leaf caused curling and drying of the leaflet tips and the mites remaining in the protected leaf fold and leaves become pale green, then yellow, and finally a copper-brown. Moreover, Burkle (2014) mentioned the early and advanced damages and the reducing fruit yield caused by $R$. indica feeding on palm fronds.

Privet mite, Brevipalpus obovatus Donnadieu

The field study revealed the presence of this pest infesting date fruits and fronds preferring the lower surface around the midrib. These mites were collected in spring and autumn as recorded in Table (1) and Fig. (1). Two peaks were recorded, the first peak was in March and April (8.05, 8.3 individuals) while the second one was in October and November (8.7, 7.9 individuals), respectively. The temperature ranged between $15-33^{\circ} \mathrm{C}$ and $15-25^{\circ} \mathrm{C}$ in spring and autumn, respectively. These mites representing $30.1 \%$ of the total collected phytophagous mites (163.25 individuals). Moreover, these mites were collected from dates in April and May where their abundance on dates exceeded their occurrence on fronds (14 individuals in April).

Our results agree with those of Mesbah (2014) who registered E. orientalis, B. obovatus and Raoiella indica from date palm trees in Giza Governorate. Childers et al. (2003) recorded Brevipalpus mites on numerous plants especially on fruits, leaves, stems, twigs, and bud tissues.

\section{B - Predaceous mites}

Five predatory mites were identified associated with different mite pests infesting date palm trees in Gamasa village, belonging to two suborders, four families, and four genera, which represented $34.67 \%$ of the total collected mites (504.35 individuals).

\section{1-Family: Phytoseiidae Berleese}

These predatory mites were observed on date palm fruits and fronds preying on different mite pests mentioned before. The field study revealed the presence of two phytoseiid mites, which represented together $56.36 \%$ of the total collected predators (174.85 individuals).

\section{Amblyseius hutu Pritchar- Baker}

Amblyseius swirskii Athias- henriot

The fluctuation in the population of these two predatory mites appeared in few numbers in summer and disappeared in winter. Two peaks were recorded in spring and autumn ranged between 8.9- 11.05 individuals and 6.05- 9.25 individuals for Amblyseius hutu and A. swirskii, when the temperature ranged between $15-33^{\circ} \mathrm{C}$ and $15-$ $38^{\circ} \mathrm{C}$ in spring and autumn, respectively (Table, 1). In addition, these mites were found in association with the phytophagus mites on date fruits ranged between 12,10 individuals for the two previous species, respectively.
These findings agree with those of El-Sanady and Mohamed (2013) who recorded A. swirskii in Giza and Suhag on date palm trees of varieties Zaghloul and Sewei. In addition, Mesbah (2014) registered these two predators on fronds and date fruits on date palms in Giza and Sharkeya.

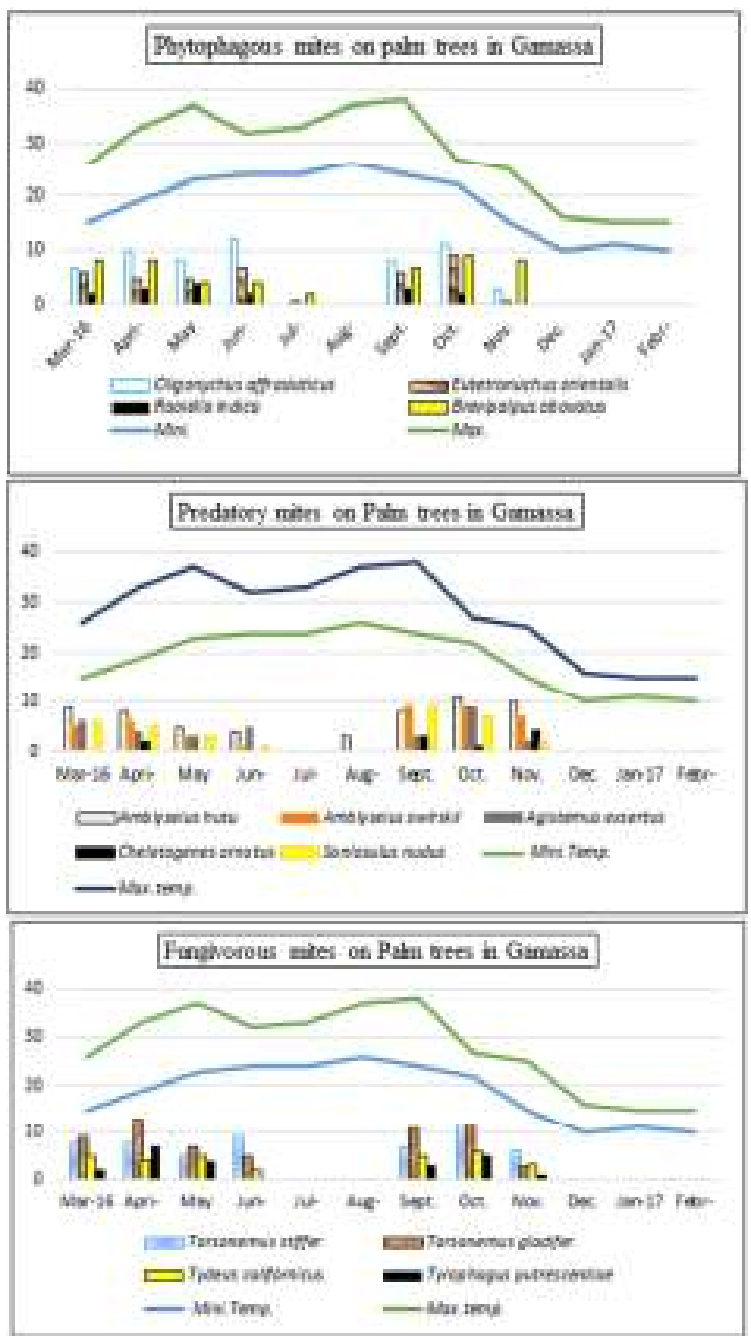

Fig.1. Phytophagous, predaceous and fungivores mites on date palm trees in Gamassa village

\section{2- Family Stigmaeidae Oudemans Agistemus exsertus Gonzalez}

Most abundant in October which averaged 9.25 individuals at $22-27^{\circ} \mathrm{C}$ then decreased and disappeared in winter months when temperature ranged between $10-16^{\circ} \mathrm{C}$, and identified again in March at $15-26^{\circ} \mathrm{C}$.

These results agree with those of El-Halawany and Abou-Setta (2013) who found this predator had one peak in spring and decreased in November then disappeared in winter months; and they reported that it was widely distributed on guava associated with tenuipalpid mites. Moreover, El-Sanady and Mohamed (2013) found this predatory mite in associated with pests infesting date palm varieties in Giza and Suhag governorates of zaghloul and sewi varieties as well, it was recorded by Mesbah (2014) in Giza and Sharkeya. Also, Ghallab (2001) was recorded this 
predator associated with the spider mite, Tetranychus urticae, Oligonychus mangiferus, Scirtothrips mangifera and different scale insects on mango trees and proved its population abundance reached the peak during September and October. On the other hand, El-Halawany et al., (1990) studied the role of $A$. exsertus in suppressing the population density of Panoychus ulmi and Aculus schlechtendali. Also, Youssef (1990) and Shoeib (1996) studied its biology on several associated prey species including eggs and immatures of tetranychoid mite, whiteflies on different vegetables, crops and fruits.

Therefore, it can be concluded that $A$. exsertus may play a role in the regulation of the pest populations on date palm trees.

\section{3 - Family Cheyletidae Leach}

Cheletogenes ornatus Canestrini and Fanzago

Population of this family was found on date palms associated with phytophagous mites and scale insects. These mites were recorded in few numbers all over the year and its peak was observed in November which averaged 3.65 individuals when temperature ranged between $15-25^{\circ} \mathrm{C}$.

Zaher (1986) reared the predator Cheletogenes ornatus on eggs and all stages of $T$. urticae Koch, E. orientalis Klein, Cenopalpus pulcher and both eggs and crawlers of several scale insects, Chrysomphalus ficus and Parlatoria oleae (Clovée). Moreover, the predator, $C$. ornatus was reared by Ibrahim (1988) on eggs and immature stages of its associated pests, Brevipalpus californicus Banks (Acari: Tenuipalpidae) and immature stages of its associated pests, Brevipalpus californicus.

\section{4 - Family Eupalopsellidae Willmann}

Saniosulus nudus Summers

A single species was recorded in this family, which found in high number of total mean of 33.45 individuals. The peaks of this mite were recorded in September and October of mean count of 9.25, 7.1 individuals, respectively, when temperature ranged between $24-38^{\circ} \mathrm{C}$.

The family Eupalopsellidae is considered as natural enemies of the associated phytophagous pests as proved by Rakha (1977) S. nudus was successfully reared on different associated prey of scale insect eggs or crawlers of Lepidosaphes pallida (Mask.), Aonidiella auranti (Mask.), Chrysomphalus ficus (Ashmead), C. dictyospermi (Morgan), L. beckii New. and Parlatoria ziziphus (Lucas). Gerson (1994) in his field studies recorded the predator, Saniosulus nudus fed on Pseudaulacaspis sp. on dwarf palm and immature stages of its associated pests, $B$. californicus.

\section{C -The miscellaneous or fungivores mites}

Three families were recorded on fronds of date palms that represented in three genera and four species. These families represented $32.96 \%$ of the total collected mites (504.35 individuals)

\section{1- Family Tarsonemidae Kramer}

Two species were found on palm trees belonging to this family, which occupied $68.6 \%$ of the total count of fungivores mites (166.25 individuals) as follow:

\section{Tarsonemus stiffer Ewing Tarsonemus gladifer Mahunka}

During the current investigation, the population of these two tarsonomid species had high abundance as shown in Table (1) and Fig. (1). The first species, Tarsonemus stiffer of total population 55.5 individuals, with three peaks; the first peak was in March, the second was in June and the third peak was in October of population reached $8.05,9.15$ and 11.5 individuals, respectively, when temperature ranged between 15-16, 2432 and $22-27^{\circ} \mathrm{C}$, respectively. The lowest population occurred in May of 5.35 individuals when the temperature raised to between $23-37^{\circ} \mathrm{C}$. However, in winter months, the fungivore mites were disappeared at low temperature ranged between $10-16^{\circ} \mathrm{C}$, and in high temperature that ranged between $24-37^{\circ} \mathrm{C}$ in July and August months.

The second tarsonemid mite, T. gladifer followed the same trend as the previous one, in addition, it infested the date fruits in May with mean of 16 individuals. The total population was recorded 58.55 individuals, their population of high abundance of two peaks, the first peak was in April (12.65 individuals) and the second one was in September and October (10.75- 11.95 individuals) when temperature ranged between $19-33,24-38$ and $22-27^{\circ} \mathrm{C}$ in April, September and October, respectively.

Krantz and Walter (2009) proved that members of this family were fed on the thin walled mycelia of fungi.

\section{2- Family: Tydeidae Kramer \\ Tydeus californicus Banks}

Survey revealed the presence of only one species in this family found in few populations on fronds in months of spring and autumn while the highest abundance was in October that averaged 6.45 individuals when temperature ranged between $22-27^{\circ} \mathrm{C}$, while the lowest abundance was 2.15 individuals in June at temperature range of $24-32^{\circ} \mathrm{C}$.

These results matches with the results recorded by El-Sanady and Mohamed (2013) in Giza and Suhag governorates.

\section{3- Family Acaridae Latreille \\ Tyrophagous putrescentiae Shrank}

Only one species collected from this family, that was found with one peak in April of population of 7.4 individuals at temperature range of $19-33^{\circ} \mathrm{C}$, while the lowest abundance occurred in November of average 0.75 individuals when temperature ranged between $15-25^{\circ} \mathrm{C}$.

Similar results were coincided with El-Sanady and Mohamed (2013), they collected this pest attacked the two varieties Zaghloul and sewi in Giza and Suhag, as well as, Mesbah (2014) in Sharkeya Governorate. Also, Krantz and Walter (2009) cited that T. putrescentiae are widespread can survive on almost anything including seeds, dead plants, live plants, dead insects, other arthropods, nematodes and fungi.

The interaction of the predatory mites and their associated phytophagous and myscellaneous mites

The correlation between predators and their associated phytophagous and saprophagous mites collected from date palm trees (Table 2) indicates that the abundance of the predators is positively strong correlated with different pests. 
Table 2.The relation of the pest mites and their associated natural enemies and the climatic factors in Gamassa

\begin{tabular}{|c|c|c|c|c|c|c|c|}
\hline \multirow[b]{2}{*}{ Taxa names } & \multicolumn{7}{|c|}{ Correlation coefficient values } \\
\hline & $\begin{array}{c}\text { Amblyseius } \\
\text { hutu }\end{array}$ & $\begin{array}{c}\text { Amblyseius } \\
\text { swirskii }\end{array}$ & $\begin{array}{c}\text { Agestimus } \\
\text { exsertus }\end{array}$ & $\begin{array}{c}\text { Cheletogenes } \\
\text { ornatus }\end{array}$ & $\begin{array}{c}\text { Saniosulus } \\
\text { nudus }\end{array}$ & $\begin{array}{l}\text { Mini. } \\
\text { Temp. }\end{array}$ & $\begin{array}{l}\text { Max. } \\
\text { Temp. }\end{array}$ \\
\hline $\begin{array}{l}\text { Oligonychus } \\
\text { afrasiaticus }\end{array}$ & 0.7 & 0.6 & 0.9 & 0.2 & 0.7 & 0.46 & 0.5 \\
\hline $\begin{array}{l}\text { Eutetranychus } \\
\text { orientalis }\end{array}$ & 0.7 & 0.7 & 0.9 & 0.2 & 0.8 & 0.5 & 0.46 \\
\hline Raoiella indica & 0.5 & 0.6 & 0.6 & 0.6 & 0.7 & 0.46 & 0.6 \\
\hline $\begin{array}{l}\text { Brevipalpus } \\
\text { obovatus }\end{array}$ & 0.97 & 0.9 & 0.8 & 0.6 & 0.8 & 0.3 & 0.4 \\
\hline $\begin{array}{l}\text { Tarsonemus } \\
\text { stiffer }\end{array}$ & 0.9 & 0.8 & 0.9 & 0.4 & 0.8 & 0.4 & 0.4 \\
\hline $\begin{array}{l}\text { Tarsonemus } \\
\text { gladifer }\end{array}$ & 0.8 & 0.8 & 0.8 & 0.4 & 0.9 & 0.4 & 0.5 \\
\hline $\begin{array}{l}\text { Tydeus } \\
\text { californicus }\end{array}$ & 0.9 & 0.9 & 0.8 & 0.4 & 0.9 & 0.3 & 0.4 \\
\hline $\begin{array}{l}\text { Tyropgagus } \\
\text { putrescentae }\end{array}$ & 0.7 & 0.7 & 0.6 & 0.4 & 0.7 & 0.3 & 0.4 \\
\hline Mini. Temp. & 0.3 & 0.24 & 0.3 & 0.1 & 0.3 & ------ & $\begin{array}{ll}--- \\
\end{array}$ \\
\hline Max. Temp. & 0.4 & 0.3 & 0.3 & 0.3 & 0.4 & ----- & ----- \\
\hline
\end{tabular}

\section{The differentiation of the predators}

Amblyseius hutu and A. swirskii recorded the highest population of total mean count $(58.55,40$ individuals), respectively, followed by Saniosulus nudus then $A$. exsertus that averaged (33.45, 32.6 individuals), respectively, while Cheletogenes ornatus recorded the lowest population of total count of 10.25 individuals.

According to the relationship between predators and their associated pests, the most of them recorded a positive strong correlation; the Saniosulus nudus harbored higher relationship to the pests ranged between $(\mathrm{R}=0.7$ \& $0.9)$, followed by $A$. exsertus $(\mathrm{R}=0.6 \& 0.9)$, then $A$. swirskii $(\mathrm{R}=0.6 \& 0.9)$, then $A$. hutu $(\mathrm{R}=0.5 \& 0.97)$, and the last Cheletogenes ornatus $(\mathrm{R}=0.2 \& 0.6)$

The correlation coefficient between predators and temperatures Table (2) ranged between $(\mathrm{R}=0.3 \& 0.5)$ and $(\mathrm{R}=0.4 \& 0.5)$ for minimum and maximum and eriophyids), some scale insects, whiteflies, stored product moths and pollen grains.

Population abundance of mites infesting palm trees in El-Kharga village

Through the field study in El-Kharga village, New Valley Governorate, the most abundant species of mite pests and their associated natural enemies on date palm trees in El-Kharga village was studied during the period between April 2016 and February 2017. Two phytophagous mites belongs to family Tenuipalpidae were detected and identified, the red palm mite, Phyllotetranychus aegypticus Sayed (Tetranychidae) and the orange mite Colopalpus (Tenuipalpus) eriophyoides Baker (Tenuipalpidae), while the predaceous mites were three genera Neophyllobius sp.( F: Neophyllobidae), $A$. exsertus (F.Stigamaeidae), Cunaxa capreolus (F: Cunaxidae) and one species of miscellaneous mite, Tydeus californicus (F: Tydeidae).

\section{1- Fluctuation the population of Phyllotetranychus aegypticus Sayed}

The red palm mite, $P$. aegypticus was recorded all over the year on the two surfaces of the frond but preferring the upper surface. Regarding the mean count of mite pest as shown in Table (3) and Fig. (2), the population appeared in few numbers on fronds of date palm in June, which averaged 2.6 individuals and 4.2 eggs when the temperatures ranged between $31-47^{\circ} \mathrm{C}$, then a peak with lower population density of the red palm mites appeared in September (13.6 motile stages \&15.9 eggs) at temperature range of $21-41^{\circ} \mathrm{C}$. The population of the pest fluctuated then reached to sharp peak in December and January (18.718.3 motile stages \& 19.9- 39.6 eggs) when the temperatures ranged between $8-18^{\circ} \mathrm{C}$. Finally, another peak was in April of lower population (12.5 individuals\& 10.5 eggs) at temperature range of $27-42^{\circ} \mathrm{C}$, then the population decreased then started to increase again.

Data indicated that high temperature during June ranged between $31-47^{\circ} \mathrm{C}$ reduced the population of $P$. aegypticus, while low temperatures in December, January and February ranged between $5-17^{\circ} \mathrm{C}$ caused significant increase in mite population.

By comparing the population of the pest on the different age stages; the population of the new age fronds suffered the highest infestation of $P$. aegypticus. Motile stages and eggs recorded a total of the mean numbers 210.6 individuals and 263.3 eggs. It could be estimated that the total numbers of the pest in the new age fronds was twice the numbers of those in the moderate age fronds (98.8 individuals) and more than triple those occupied in the old age fronds (56.7 individuals). It is obvious that there was a sharp peak in December representing the high abundance of this pest on the new age fronds (39.7 individuals), while January and February recorded the highest biomass of eggs 41-66.1 deposited by the red palm mites.

Statistical differences were observed in motile stages of the red palm mite and their eggs numbers among the three age stages of frond at $\mathrm{P} \geq 0.05$. According to LSD, there was a high significant difference between individual means of the new fold and those of the two other age stages, while there were no significant differences between mean values of the two other age stages (old and median fronds). In case of egg stages, the average counts of the deposited eggs in the three age stages of frond registered no significant differences between mean of their values, but there was a high significant difference between mean of new fronds 21.9 eggs and mean of old fronds 7.13 eggs and the LSD value at $5 \%$ was 9.1 . 
Ola M. Roshdyet al.

Table 3. The monthly mean number of the red palm mite, Phyllotetranychus aegypticus / frond of different ages between April 2016 and March 2017

\begin{tabular}{|c|c|c|c|c|c|c|c|c|c|c|}
\hline \multirow{2}{*}{ Date } & \multicolumn{3}{|c|}{ Motile stages / fronds } & \multirow{2}{*}{ Means } & \multicolumn{3}{|c|}{ Eggs / fronds } & \multirow{2}{*}{ Means } & \multicolumn{2}{|c|}{ Temperatures } \\
\hline & old & median & New & & old & median & new & & Mini. & Max. \\
\hline April & 4.9 & 5.6 & 26.9 & 12.5 & 2 & 3.3 & 26.2 & 10.5 & 27 & 42 \\
\hline May & 7.1 & 6.9 & 12.6 & 8.9 & 7 & 12.5 & 21.1 & 13.5 & 27 & 45 \\
\hline June & 1 & 2.3 & 4.5 & 2.6 & 1.4 & 3.4 & 7.7 & 4.2 & 31 & 47 \\
\hline July & 2 & 3 & 12.5 & 5.8 & 1.5 & 2.5 & 10 & 14 & 24 & 38 \\
\hline August & 2.8 & 3.7 & 19.9 & 8.8 & 2.2 & 1.4 & 11 & 4.9 & 27 & 41 \\
\hline September & 10.2 & 14.7 & 16 & 13.6 & 14.1 & 18 & 15.6 & 15.9 & 21 & 41 \\
\hline October & 10 & 8.1 & 15.7 & 11.3 & 11.1 & 7.6 & 16.4 & 11.7 & 16 & 32 \\
\hline November & 2.9 & 10.7 & 14.4 & 9.3 & 3 & 35.6 & 12.5 & 17 & 14 & 28 \\
\hline December & 0.2 & 16.2 & 39.7 & 18.7 & 0.5 & 26.1 & 33.2 & 19.9 & 10 & 18 \\
\hline January & 9.7 & 17.5 & 27.8 & 18.3 & 31.9 & 46 & 41 & 39.6 & 8 & 17 \\
\hline February & 2.2 & 5.1 & 8.4 & 5.2 & 8.6 & 16.5 & 66.1 & 30.4 & 5 & 17 \\
\hline March & 3.7 & 5 & 12.2 & 6.9 & 2.3 & 2.6 & 2.5 & 2.5 & 12 & 28 \\
\hline Total & 56.7 & 98.8 & 210.6 & 122 & 85.6 & 175.5 & 263.3 & 10.5 & & \\
\hline Means & 4.7 & 8.2 & 17.5 & & 7.13 & 14.6 & 21.9 & & & \\
\hline LSD at $5 \%$ & & 4.7 & & & & 9.1 & & & & \\
\hline
\end{tabular}

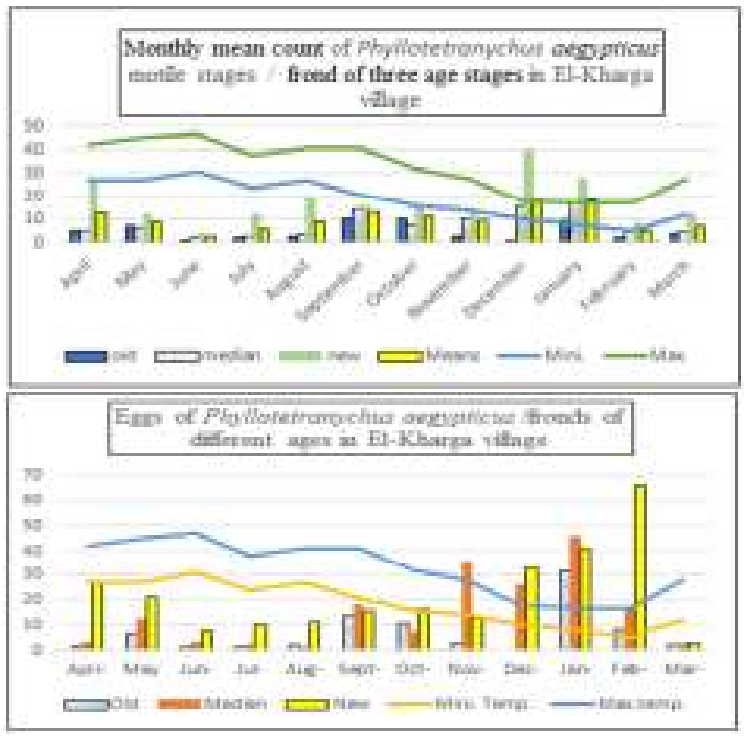

Fig. 2. Infestation level of Phyllotetranychus aegypticus (motile stages \&eggs) on fronds of three age stages in El-Kharga village
2- Fluctuation the population of Colopalpus eriophyoides Baker

The orange palm mites, C. eriophyoides, were observed on the two surfaces of the fronds preferring the lower surface. Data in Table (4) and Fig. (3) showed the population of the pest which appeared in few numbers on fronds of palm in June of total average ( 0.7 individuals\& 1.03 eggs) when the temperatures ranged between $31-47^{\circ} \mathrm{C}$, then the population of the pest increased gradually reaching a peak of few individuals (7.3 individuals\& 5.4 eggs) at temperature range of $21-41^{\circ} \mathrm{C}$. A sharp peak occurred in November (13.2 individuals \& 9.5 eggs) when the temperatures ranged between $14-28^{\circ} \mathrm{C}$, then the population decreased in December to a peak of lower individuals than the previous one (8.7 individuals\& 14.4 eggs) at temperature range of $10-18^{\circ} \mathrm{C}$. Data indicated that high temperature during June reduced population of $C$. eriophyoides, while moderate temperature during November caused significant increase in mite population.

Table 4. The monthly mean number of the orange palm mite, Colopalpus eriophyoides / fronds of different ages between April 2016 and March 2017

\begin{tabular}{|c|c|c|c|c|c|c|c|c|c|c|}
\hline \multirow{2}{*}{ Date } & \multicolumn{3}{|c|}{ Motile stages / fronds } & \multirow{2}{*}{ Means } & \multicolumn{3}{|c|}{ Eggs / fronds } & \multirow{2}{*}{ Means } & \multicolumn{2}{|c|}{ Temperatures } \\
\hline & old & median & new & & old & median & new & & Mini & Max \\
\hline April & 6.7 & 0.8 & 4.1 & 3.9 & 1.7 & 0.3 & 1.4 & 1.13 & 27 & 42 \\
\hline May & 4.4 & 2 & 2 & 2.8 & 1.7 & 1.5 & 0.2 & 1.13 & 27 & 45 \\
\hline June & 0.7 & 0.4 & 1 & 0.7 & 0.4 & 1 & 1.7 & 1.03 & 31 & 47 \\
\hline July & 2.5 & 1.5 & 1.5 & 1.8 & 2 & 0.7 & 1 & 1.2 & 24 & 38 \\
\hline August & 4.8 & 2.1 & 1.5 & 2.8 & 3.6 & 0.4 & 0 & 1.3 & 27 & 41 \\
\hline September & 2.3 & 12.2 & 7.4 & 7.3 & 1.9 & 8.1 & 6.2 & 5.4 & 21 & 41 \\
\hline October & 8.5 & 1.7 & 4.6 & 4.9 & 9 & 1 & 2 & 4 & 16 & 32 \\
\hline November & 30.2 & 3.2 & 6.3 & 13.2 & 22.7 & 2.7 & 3.2 & 9.5 & 14 & 28 \\
\hline December & 14.1 & 4.1 & 8 & 8.7 & 23.2 & 7.2 & 12.9 & 14.4 & 10 & 18 \\
\hline January & 8.5 & 3.3 & 4.1 & 5.3 & 14.9 & 7.4 & 0.6 & 7.6 & 8 & 17 \\
\hline February & 4.5 & 1.2 & 1.4 & 2.4 & 11.2 & 1.2 & 1.3 & 4.6 & 5 & 17 \\
\hline March & 3.3 & 1.2 & 1.1 & 1.9 & 0.5 & 0.1 & 0.1 & 0.2 & 12 & 28 \\
\hline Total & 90.5 & 33.7 & 43 & 55.7 & 92.8 & 31.6 & 30.6 & 51.7 & & \\
\hline Means & 7.5 & 2.8 & 3.6 & & 7.7 & 2.6 & 2.5 & & & \\
\hline$\overline{\mathrm{LSD}}$ at $5 \%$ & & 3.9 & & & & 5 & & & & \\
\hline
\end{tabular}

It is obvious that the old age fronds recorded the highest infestation of the orange palm mites, motile stages and eggs with average 90.5 individuals and 92.8 eggs. It could be estimated that the total numbers of the pest in the 
old age fronds were twice the numbers of those of the new age fronds (43 individuals) and approached triple those which occupied in the median age fronds (33.7 individuals). Obviously, there was a sharp peak in November represented the high abundance of this pest followed by another one in December of lower population on the old age fronds (30.2, 14.1 individuals), respectively. November and December recorded the highest biomass of 22.7-23.2 eggs deposited by the orange palm mites.

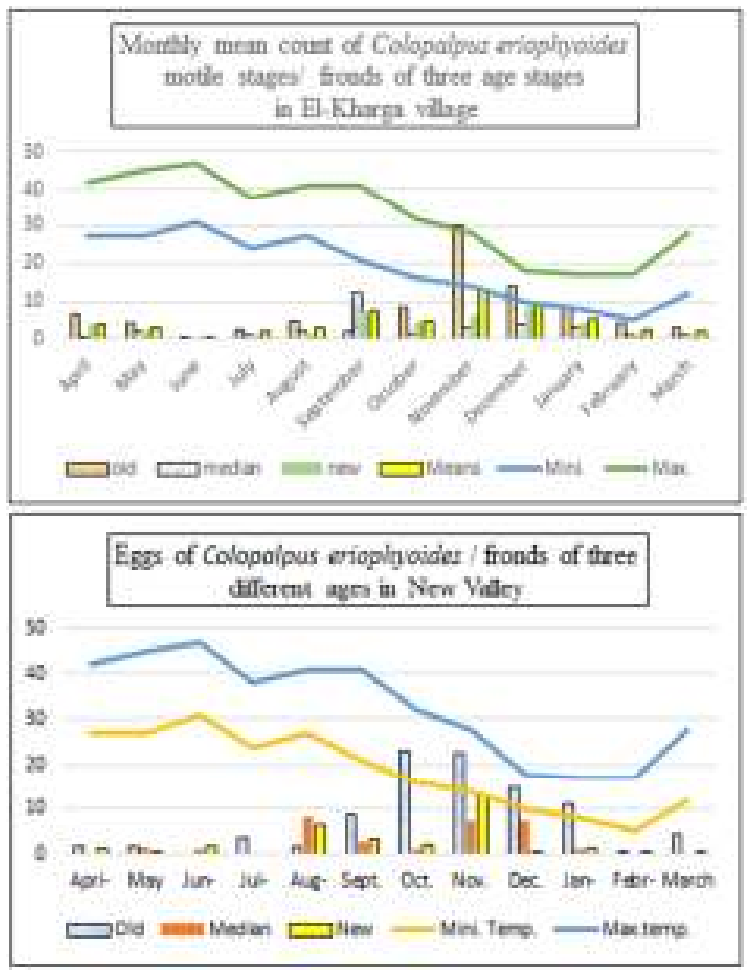

Fig. 3. Infestation level of Colopalpus eriophyoides (motile stages \&eggs) on fronds of three age stages in El-Kharga village

These results were in accordance with findings of Baker and Wharton (1952) who described for the first time the orange mite, Colopalpus eriophyoides (Baker) (=Tenuipalpus eriophyoides) on date palm in Basrah. Moreover, Al-Gboory (1987) recorded this mite pest in his thesis as a pest of palm trees and he studied the taxonomy of tenuipalpid mites in Central Iraq. Moreover, Mohamed et al., (2014) recorded the males and females of this species for the first time in Egypt, which were collected from fronds of palm trees in Suhag governorate through the Plant survey programs.

According to LSD, there was a significant difference between the mean values of motile individuals of the old frond and the median age fronds (7.5, 3.6 individuals, respectively, and LSD = 3.9), while there were no significant differences between mean values of the two other age stages.

In case of eggs, there was no significant difference between means of eggs, which were deposited on the old fronds, and the other two age stages.

The correlation coefficient between phytophagous mites and temperatures $(\mathrm{R}=-0.4)$ for minimum and maximum temperature was weak negative correlation.
Therefore, we can conclude that, as the temperature increases the phytophagous mites population decreases, and vice versa.

\section{Predaceous mites}

\section{Neophyllobius sp.}

A single species was recorded in this family, which was found in high number of total mean of 28 individuals in April at temperature range of $27-42^{\circ} \mathrm{C}$ and $11 \& 8$ individuals in October and November at temperature range of $14-32^{\circ} \mathrm{C}$, then did not appear again perhaps due to an error in getting samples or due to its transfer.

The predator, Neophyllobius mangiferus Gomaa was reared by Hassan (1976), on Chrysomphalus ficus Ashmead, and confirmed its predatory feeding habit and its feeding effectiveness, which increased with the predator development.

\section{Agestimus exsertus Gonzalez}

Only one species was found of 11 individuals on new fronds in April. Fathipour and Maleknia (2016) reported that the predatory mite, Agistemus exsertus Gonzalez is the most common stigmaeid on some fruit trees, vegetables, ornamentals, field crops, and wild plants and the mostly existed predator feeding on phytophagous mites (tetranychids, tenuipalpids, and eriophyids), some scale insects, whiteflies, stored product moths, and pollen grains.

\section{Cunaxa capreolus Berlese}

Only one species of five individuals were collected in February at temperature range of $5-17^{\circ} \mathrm{C}$.

Majidi and Akrami (2013) surveyed mites associated with the date palm (Phoenix dactylifera L.) in Larestan, Iran and listed it as an aerial predator associated with phytophagous mites.

\section{Miscellaneous mites}

\section{Tydeus californicus Banks}

A single species was recorded in this family, softbodied mite found in few numbers of total mean of 14.3 individuals. Its peak was observed in January which averaged 4.3 individuals at temperature range of $8-17^{\circ} \mathrm{C}$

Baker and Wharton (1952) described Tydeus californicus Banks as a predator, some are fungivorous, and some are phytophagous. Zaher (1986) collected $T$. californicus from several truck crops and fruit trees allover Egypt.

As a consequence of the highly usage of pesticides in the last years, several mite pests build-up a high population causing serious damage to their host due to harmful impact on natural enemies. The usage of acaricides in order to control pests should be done in economically and environmentally ways. The correct use of acaricides will delay the onset of resistance and give natural enemies. Right using of acaricides provides possible chance of reducing densities of actual and potential pests.

\section{REFERENCES}

* http://www.socscistatistics.com/tests/pearson

AI-Gboory, I. (1987). Taxonomic Studies of False Spider Mites (Acari: Tenuipalpidae) In Central Iraq. Thesis Institut fur angewandte Zoologie der Rheinischen Friedrich -Wllhelms -Universitit Bonn, Ph. D. Thesis 204 pp.

Baker, E.W. and Wharton, G.W. (1952). An Introduction to Acarology. The Macmillan Co., New York, 465 pp. 
Burkle, C.J. (2014). Plant-feeding mite pests, May 2014. Educational Disclaimer and Citation, $14 \mathrm{pp}$.

Childers, Carl C.; French, J.V. and Rodrigues, JCV (2003). Brevipalpus californicus, Brevipalpus obovatus, B. phoenicis and B.lewisi (Acari: Tenuipalpidae): A Review of Their Biology, Feeding Injury And Economic Importance.May, Exp. \& Appl. Acarol., 30 (1): 5-28

El-Halawany, A.S and Abou-Setta, M.M. (2013). Mites inhabiting guava trees and their dynamics in relation to weather factor and plant phenology. Acarines, 7 (2): 17- 21.

El-Halawany, M. E.; Abou-El-Ela, R. G. and Esmaeil, H. (1990). Population dynamics of mites and their natural enemies on apple and apricot trees. Agric. Res. Rev. 68(1): 59-66.

El-Sanady, Mariam A. and Mohamed, Azza A. (2013). Biodiversity and seasonal abundance of mites associated with two varieties of date palm in Giza and Suhag Governorates, Egypt. Proceedings of the Fifth International Date Palm conference, Acarines, 7 (2): 57- 62.

Fathipour, Y. and Maleknia, B. (2016). Ecofriendly Pest Management for Food Security. //www. sciencedirect.com/topics/agric- biol.-sc./pred-mite.

Gerson, U. (1994). The Australian Eupalopsellidae (Acari: Prostigmata). Invertebrate-Taxonomy 8(1): 63-73.

Ghallab, Mona M. (2001). Ecological, biological and morphological studies on some predaceous mites (Suborder:Actinedida). Ph. D. Thesis, Fac. Sc. Cairo Univ. 244 pp.

Hassan, M.F. ( 1976). Studies on some prostigmatid predators. M.Sc. Thesis 70pp. Fac. Agricult., Cairo Univ.

Ibrahim, S.M. (1988). Ecological and biological studies on some predaceous mites associated with citrus trees in Egypt. Ph.D. Thesis Fac. Agricult. Cairo Univ. 148pp.

Jeppson, L.R., Keifer, H.H. and Baker, E.W. (1975). Mites injurious to economic plants. Univ. Calif. Press, Berkeley, $614 \mathrm{pp}$.

Kloft, W. and Kunkel, H. (1969). Die Bedeutung des Ortes der Nahrungsaufnahme pflanzensaugender Insekten fur die Anwendbarkeit von Insektiziden mit systemischer Wirkung. Z. Pfl.- Krankh., 76: 1-8.

Krantz, G.W. and Water, D.E. (2009). A Manual of Acarology. Oregon State University Book Stores, $807 \mathrm{pp}$.

Majidi, Maryam and Akrami, M.A. (2013). Mites associated with the date palm (Phoenix dactylifera L.) in Larestan (Fars province), southern Iran. Persian Journal of Acarology, Vol. 2, No. 2, pp. 335-339.
Mesbah, Amira E. (2014). Mites inhabiting date palm trees and their dynamics with reference to reproduction and life table parameters of Raoiella indica Hirst (Tenuipalpidae) at different temperatures. Acarines, 8 (1): $29-38$

Mohamed, Azza A.; Mohamed , A.M. and El-Zoghby, I.R.M. (2014). First record and re-description of Tenuipalpus eriophyoides Baker (Acari: Tenuipalpidae) in Egypt. Acarines, 8 (1): 25-28.

Negm, M.W., Moraes, G.J. and Perring, T.M. (2007). Mite Pests of Date Palms Sustainability in Plant and Crop Protection, Sustainable Pest Management in Date Palm: Current Status and Emerging Challenges 12: pp347-389

Perring, T.M.; Farrar, C.A. and Oldfield, N.G. (1996). Sampling techniques (c.f. Lindquist, EE; Sabelis, MW; and Bruin, J. Eriophyoid mites, their biology natural enemies and control. World Crop Pest, Amesterdam. 6: 367-376.

Radwan, Sawsan G. and Attia, Angel R. (2013). Field study on the two mite species, Hemisarcoptes coccophagus Meyer (Astigmata: Hemisarcoptidae) and Phyllotetranychus aegyptiacus Sayed (Prostigmata: Tenuipalpidae) on two varieties of date palm trees at Giza Governorate. Acarines, 7(2): 29-35

Rakha, M.A. ( 1977). Studies on some predaceous raphignathoid mites inhabiting fruit trees. M.Sc. Thesis 99pp. Fac. Agricult. Cairo Univ.

Rodrigues, José C.V.; Ochoa2, R. and Kane3, E.C. (2007). First Report of Raoiella Indica Hirst (Acari: Tenuipalpidae) and Its Damage to Coconut Palms in Puerto Rico and Culebra Island. Internat. J. Acarol. Vol. 33, No. 1: 3 - 5.

Shoeib, A. (1996). Biological and ecological studies on some predaceous mites. Ph.D. Thesis Fac. Agricult. Cairo Univ. 156 pp.

Wilkinson and Leland (1999). "Statistical Methods in Psychology Journals; Guidelines and Explanations". American Psychologist. 5 (8): 594 604.

Youssef, A.E. (1990). Biological studies on the predaceous mite $A$. exsertus Gonz. (Acari: Stigmaeidae) M.Sc. Thesis Fac. Agricult. Menoufeia Univ. 100pp.

Zaher, M.A. (1986). Survey and ecological studies on phytophagous, predaceous and soil mites in Egypt. II. A predaceous, non-predaceous mites (Nile Valley and Delta) PL. 480 Program USA. 567pp.

Zaher, M.A.A., Wafa, A.K. and Yousef, A.A. (1969). Biological studies on Raoiella indica Hirst and Phyllotetranychus aegyptiacus sayed infesting date palm trees in U.A.R. (Acarina : Tenuipalpidae) Z. Angew. Entomol. 63; 406-411.

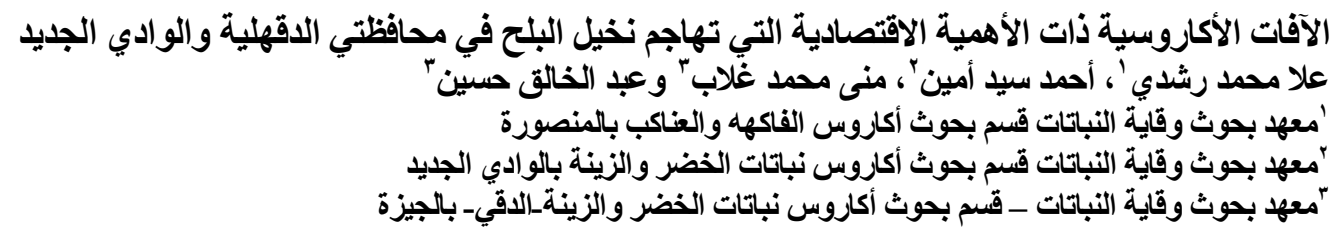

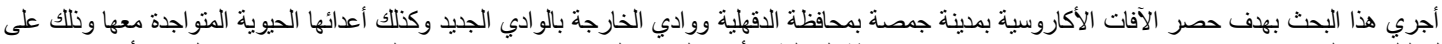

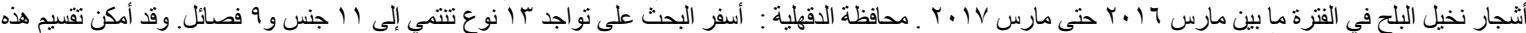

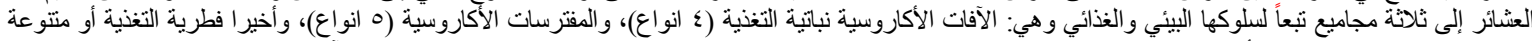

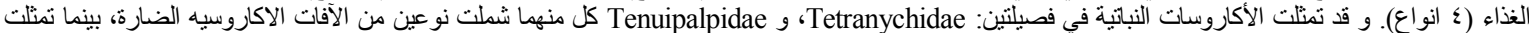

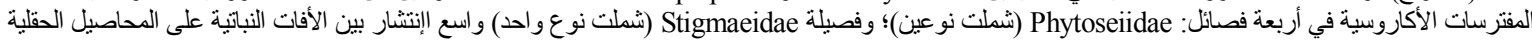

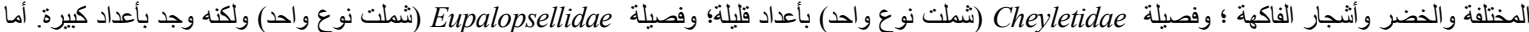

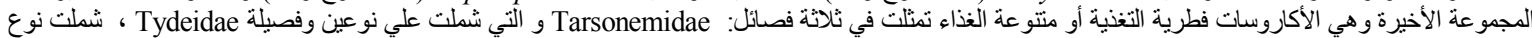

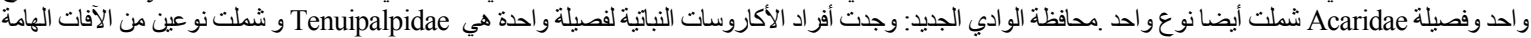

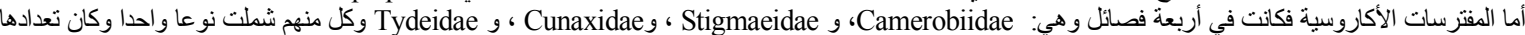

